\title{
Dez Anos dos Cadernos de Saúde Pública!
}

C om a edição do quarto fascículo do volume 10 , concluímos uma década de publicação ininterrupta. Ao longo destes anos, os Cadernos evoluíram e amadureceram, ocupando no presente um lugar de destaque não somente entre as publicações científicas brasileiras, como também entre suas congêneres latino-americanas.

Para melhor visualizarmos a evolução dos Cadernos, nada melhor que algumas estatísticas. Entre 1985 (volume 1) e 1993 (volume 9), o número médio de artigos por volume foi de, aproximadamente, 27. No volume 10 foram publicados 62 trabalhos. Dentre os autores que publicaram no período 1985-1991, 48\% eram vinculados a outras instituições que não a Escola Nacional de Saúde Pública (Ensp), 5\% dos quais estrangeiros (para fins desta análise, artigos assinados por autores da Ensp em co-autoria com pesquisadores de outras instituições foram computados como "artigos da Ensp"). A partir de 1992, o percentual de autores de fora da Ensp alcançou 58\%, chegando à cifra de 65\% em 1994 . Neste mesmo período, a proporção de contribuições de autores estrangeiros atingiu $12 \%$.

O ano de 1994 representou um crescimento da ordem de $230 \%$ em relação ao número médio de artigos que vinham sendo publicados até então, com uma representação cada vez mais marcante de autores de outras instituições brasileiras e estrangeiras. Estes dados refletem crescente penetração e credibilidade dos Cadernos perante a comunidade científica. Para tal, contribuiu não somente a periodicidade de sua publicação, como também as profundas mudan- ças de layout e diagramação implementadas, a partir do volume 8 . Tais mudanças tornaram a revista visualmente mais atraente. A indexação dos Cadernos em diversas bases de dados, como Lilacs, CAB Abstracts e Repidisca, dentre outras, permitiu a divulgação dos artigos publicados em inúmeros indexadores especializados, atraindo, portanto, crescente número de autores. No presente, o processo de revisão e publicação de manuscritos está levando, em média, cerca de 10 meses.

Os membros do Conselho Editorial, incluindo os consultores $a d$ hoc, são pesquisadores reconhecidamente conceituados em seus campos de atuação. Devo destacar o cuidado de nossos consultores na elaboração de seus pareceres, um aspecto fundamental para o adequado funcionamento do sistema de revisão pelos pares.

Como não poderia deixar de ser, os Cadernos são uma realização de muitos, cujos nomes seria impossível listar neste curto espaço. Devo mencionar o apoio incondicional que os Cadernos têm recebido da direção da Escola Nacional de Saúde Pública. Mais recentemente, o auxílio concedido pelo programa de apoio a publicações científicas do CNPq/Finep tem sido fundamental para o aperfeiçoamento da revista, imprimindo-lhe maior autonomia e agilidade. Por fim, o reconhecimento à equipe da Secretaria de Desenvolvimento Educacional da Ensp, sem a qual, simplesmente, não teríamos a nossa revista.

Carlos E. A. Coimbra Jr. Editor 


\section{Ten Years of Cadernos de Saúde Pública!}

$A$ s we release this fourth issue of Volume 10, we conclude one whole decade of this uninterrrupted publication. Over the course of these ten years, the Cadernos de Saúde Pública (Reports in Public Health) have evolved and matured, occupying an outstanding place among both Brazilian scientific publications and their Latin American equals as well.

In order to get an idea of how the Cadernos have evolved, nothing better than a few statistics. From 1985 (Volume 1) to 1993 (Volume 9), the mean number of articles per volume was approximately 27. In Volume 10, a full 62 articles were published. Among the authors that published articles from 1985 to 1991 , some $40 \%$ were affiliated with institutions other than the Escola Nacional de Saúde Pública (ENSP), five percent of whom were foreigners (for the purposes of this analysis, articles signed by authors from ENSP in coauthorship with researchers from other institutions were considered "articles form ENSP"). In 1992, 58\% of the articles were written by authors from outside ENSP, and this figure reached $65 \%$ in 1994 . During this same period, contributions by foreign authors increased to $12 \%$ of the total.

In 1994, there was an increase of some $230 \%$ in the mean number of articles published, with a marked rise in the number of authors from other institutions, both Brazilian and foreign. These figures reflect the growing spread and credibility of Cadernos in the scientific community. These were the result of both the journal's periodicity and the profound changes in its layout and graphic design beginning with Volume 8 . These changes made the journal more visually attractive. The indexing of Cadernos in various data bases, like
Lilacs, CAB Abstracts, Repidisca, and others, allowed for the dissemination of articles published in numerous specialized indexes, thus attracting a growing number of authors. At present, the reviewing and editing process takes ten months on average, from the receipt of manuscripts to publication in the journal.

Members of the Editorial Board, including the ad hoc consultants, are renowned researchers in their respective professional fields. I should highlight the care taken by our consultants in completing their reviews, a fundamental aspect for the proper functioning of a peer review system.

The Cadernos are an achievement pertaining to many researchers, and it could hardly be otherwise. It would be impossible to list all of these professionals in this limited space. However, I should mention the unwavering support the Cadernos have received from the president and staff of the Escola Nacional de Saúde Pública. More recently, funding from the program to support scientific publications at the Brazilian National Research Council (CNPq/FINEP) has allowed us to improve the journal by making it more agile and independent. Finally, I should thank the Office for Educational Development at ENSP, without whose untiring efforts we simply would not have a journal.

Carlos E. A. Coimbra fr. Editor 